\title{
Everyday violence and Mai Mai militias in Eastern DRC
}

What would you do if the state was a man? I'll kill him. ${ }^{1}$

\section{From words to weapons}

A Ithough there were skirmishes, especially throughout the 1990s, Chapter 3 has already exposed how the first phase of the conflict was the defining moment in which the armed mobilisation of subordinate classes took place. The fact that the AFDL war was conducted under the guise of a national liberation movement and led by Laurent-Désiré Kabila succeeded in reviving the Mai Mai historical sentiment of fighting against oppression and colonial conquest (Dunn 2002: 55). As noted in Chapter 3, Kabila had been a member of Lumumba's cabinet and fought with Pierre Mulele, who led one of the biggest revolts against Mobutu and was a driving force for the creation of the Simba and Mai Mai popular militias in the 1960s. ${ }^{2}$ During the 1996 and 1998 wars, Mai Mai militias generally fought on the side of the Government to repel the RCD rebellion and the Rwandan, Ugandan and Burundian invasions. However, they remained autonomous from the army, and since the transition most groups have developed an anti-government stand. The Mai Mai militias consider themselves inheritors of a tradition of resistance that dates back to the struggle against colonialism and beyond. In a note from a Mai Mai Padiri combatant, this historical tradition of resistance is explained as follows:

We cannot stop thinking and we cannot stop sending the calls to the mystery that surrounds us everywhere; that is, we cannot stop resisting evil. It is within that approach that the Movement of Mai-Mai resistance was born, which has its distant origins in the domination of man by man [...] Already in 1481, the king Nzinga Panju was opposed to Portuguese occupation in his kingdom; in 1682, the prophet Chimpa Vita resisted against the implantation of foreign power in the kingdom of Kongo, she was burnt alive. In 1942, in the kingdom of the Bahunde, where the Bakumu live, in Masisi, in one of the hunters' villages, in Ntoto, Mandayi told Sindikiza that his brother Yusufu Kitawala in the cultural struggle against foreign 
occupation had a formula that protected men against all attacks from bladed or fire weapons by the enemy. In 1951, Simon Kimbangu died in exile, Patrice Lumumba and Pierre Mulele and recently Desire Kabila, killed 16/01/2001 for having brandished and lifted the spirit of a profound love for the homeland. (Unknown Author 2005: 1)

Hence the AFDL rebellion awakened a latent revolt. However, the subsequent militarisation has set peasants on the path to a permanent state of armed conflict (Amuri Misako 2008). This permanent conflict is not because rural classes have since maintained a popular uprising, but because the war has made them primary targets. The RCD rebellion in support of neighbouring countries' invasion of the DRC in 1998-2003, the insecurity provoked by the different CNDP uprisings and the ongoing presence of foreign and national armed groups represent a continuation of the self-defence and liberation agenda. The strategies undertaken for surviving and confronting war are inseparable from the strategy of joining armed militias as a way of 'reacting against their marginalisation and exclusion' (Vlassenroot 2002: 150). The means used are largely conditioned by the historical moment in which actors are embedded.

Nevertheless, there is great variety amongst Mai Mai militias. While some groups abide by a firm code of conduct and are attached to an agenda of liberation and social justice, others have also turned into predators of the population (e.g. Rasta) (UPDI and LPI 2009). The attacks of the Mai Mai Cheka in JulyAugust 2010, mentioned in Chapter 3, are a primary example. They included systematic rape and other crimes in 15 villages in Walikale in alliance with the FDLR. Mai Mai Cheka was born out of a power-struggle for the control of the largest cassiterite mine in the DRC, which had been given to FARDC/CNDP after the 23 March agreements in 2009, to the detriment of the FARDC/ex-Mai Mai brigade of Colonel Samy that had controlled it previously (UN Group of Experts 2010b: para. 34-43). Other militias, as already seen, have been successfully co-opted into state/elite networks to be used for proxy wars between the DRC (e.g. PARECO) and Rwanda (e.g. Mundundu 40 - now defunct) (Hoebeke et al. 2009: 132; UN Group of Experts 2008b: 100-3). The popular character of some militias is therefore challenged by the fact that militias ally with and pursue elite agendas. Yet this is not static; there is an important element of unreliability and contingency, meaning that Mai Mai groups are likely to betray these elites and form new groups.

Despite these complexities, the history and current dynamics in many Mai Mai militias make them representatives of the ways in which rural classes have used or joined these militias as a form of resistance to the effects of domination. The deepening of the statebuilding strategies in the last decade has implied the militarisation of the Kivus, of which Mai Mai militias have been the primary targets. The terms set for Mai Mai demobilisation, the ongoing context of war 
and poverty, and the FARDC being deployed as a representation of state authority are all sources of distrust and rejection of state authority. The consolidation of administrative and military positions in the hands of the CNDP, the CNDP and M-23 uprisings, the continuous presence of the FDLR along the Kivus and the military operations by FARDC have fuelled Mai Mai nationalist sentiments. The role of the Mai Mai as militias of self-defence and vehicles of political participation has become even more prevalent. They provide a way to defend and advance agendas of security provision, control of land and local political authority. This last element permeates Mai Mai ideology and represents the long-term aspirations of the Congolese peasantry.

Understanding everyday forms of resistance in the DRC implies acknowledging that the fact that they are based on the lack of direct confrontation and on practices undertaken to attract the minimum amount of repression does not necessarily mean they are without violence. Resistance is shaped by the political context in which it is embedded and practices do not define resistance per se. Three aspects need to be analysed in order to understand the role of violence as a tool of resistance: the context of war, the motivations that popular classes have to support or create armed groups, and how extensive this popular support is. Whereas the context of war was analysed in previous chapters, this one will focus on the other two aspects - motivations and support. These two aspects account for the defining elements of resistance, including the denial/mitigation of claims and the agenda-advancing on the part of popular classes. They also show different gradients in the practices. Attacking the military or other armed groups is a denial of the state's claim on the monopoly of violence and a form of mitigating state-making-related violence. This is a claim-regarding overt practice of resistance. Conversely, using Mai Mai militias to provide security is a self-regarding practice. The violence generated by the context is used and transformed as a self-serving mechanism to counter precisely the effects of violence. In so far as the state is experienced as a form of predation and insecurity, subordinate classes' motivations have at their core the rejection of state authority and state-making agendas. They strive to provide security and protection, while advancing agendas of political participation, representation and land. However, these motivations are not static, nor is the support subordinate classes give to these militias; rather, the support is contingent and changing. Mai Mai militias tend to be formed from specific ethnic groups, or those who are closely related, although not all members of an ethnic group or of a particular area would support the local militia.

Mai Mai militias pose multiple challenges to an account of resistance. In order to address these challenges and to analyse violence as part of the everyday practices of resistance, the chapter first discusses the motivations then the support for these militias. The focus of this chapter is on Fizi, where Mai Mai Yakotumba operates, and on Bunyakiri, with ex-Simba Mai Mai/MRS and 
current Raïa Mutomboki. These cases display an anti-government agenda (having less government interference as a result), as cases that have confronted the effects of state-making and whose relation to their constituencies illustrates the dynamics and motivations for popular support. These militias do not represent a continuous popular uprising or a model for ethical resistance. They are an effect of war; and they are ultimately representative of the heterogeneity in the practices of resistance.

\section{Motivations}

The mainstream narrative of Mai Mai militias is that they seek their enrichment or to attack antagonistic ethnic groups, where any discourse of social justice and grievances is just a façade (ADEPAE et al. 2011; Alden et al. 2011). ${ }^{3}$ Those who have studied these militias in greater depth observe that their motivations are more complex (Acker and Vlassenroot 2001; Amuri Misako 2007, 2008; Hoffmann 2007; Jourdan 2004; Maindo Monga Ngonga 2007; Vlassenroot 2002). ${ }^{4}$ Researchers have identified four categories of violence as anti-government, income-generating, maintaining social control over the group they operate from and symbolic, where targets represent their beliefs or identity. ${ }^{5}$ For Verweijen (2015), it is income generation and (re)production and expansion of control over the ethnic community they represent that are most significant. Other studies have identified marginal conditions of living, poverty and general disenfranchisement as the main reasons for combatants to join militias (Lubala Mugisho 2000: 209-10; Vlassenroot 2000: 94-6). Lubala Mugisho adds historical factors as important for the emergence of these militias. Yet others have seen the militias as a form of rural political mobilisation, motivated by a rejection of the status quo, and aspirations for social justice (Acker and Vlassenroot 2001; Amuri Misako 2008; Hoffmann 2007; Vlassenroot 2002).

The formation of Mai Mai militias cannot be delinked from the history of uprisings since colonial times. However, at the present time their presence cannot be separated from the context of war. What Misako calls the "militianisation' of life means that self-management and security provision, in the context of relative state absence, as well as the pursuit of political agendas and aspirations through armed groups is an 'effect' of the context of violence (Amuri Misako 2007: 21). Violence becomes a form of political participation where power is asserted through violence. In the war context of the DRC, Acker and Vlassenroot argue, violence is the language through which many young marginalised Congolese demonstrate their distrust of state institutions, resist the conditions in which they live and aim at a more egalitarian order (Acker and Vlassenroot 2001: 104 and 106). Joining an armed group could be generally inscribed in the dynamics of contestation of the state since these conditions of 
living tend to be seen as the consequence of an unjust social order in which the state is directly responsible or complicit.

These dynamics of war and state contestation, which, as Prunier argues, come both 'from above and from below', signal that uses of violence can be read as furthering elite or personal agendas (1991: 4). The political meaning granted to these motivations is a defining factor in analysing popular classes as politically minded or as politically manipulated. ${ }^{6}$ Following a Scottian framework, selfcentred individual and collective motivations come together in the everyday politics of non-elites. These militias represent an arena where patterns of resistance to practices of coercion and extraction unfold. The examples from Fizi and Bunyakiri explored in this section illustrate this point by analysing, firstly, the rejection and distrust of the state, and secondly, how these motivations are linked to community protection and security as important underlying agendas, and to land and political participation as important aspirations. ${ }^{7}$

\section{Rejection and distrust}

\section{Fizi: Yakotumba}

Mai Mai Yakotumba was created in 2007 but has a significant rebel history. ${ }^{8}$ Its core members fought in the various brigades that were part of the secondbiggest Mai Mai structure in South Kivu, led by General Daniel Dunia, during the 1998-2003 war. General Dunia's troops resisted both Kabila's AFDL and the RCD rebellion. Not only were both of these uprisings seen as an invasion, but Dunia's resistance was the only form of protection against the brutal violence with which these uprisings were undertaken. Yakotumba's and the previous Dunia's troops were composed mostly of Babembes, who are the majority ethnic group in the area of Fizi. ${ }^{9}$ The Babembe take pride in claiming that they resisted Mobutu for over 25 years, arguing that they 'vehemently hate all dictatorial political systems that violate fundamental human rights' (Unknown author 2010: 16). The same articulation has been seen in the increasing distrust towards the Government throughout the transitional period.

When the transition in 2006 brought in the different plans for Mai Mai demobilisation and reintegration, not all of General's Dunia's troops were successfully disengaged. Refractory elements, especially William Amuri Yakotumba, rejected the demand to redeploy his troops out of Fizi. Several military and political factors were in place for this decision. ${ }^{10}$ Militarily, the Banyamulengue Mai Mai group operating in the high plateaus of South Kivu, the FRF, did not reintegrate into the army and pushed for the constitution of the territory of Minembwe in order to have an independent administration from Fizi. ${ }^{11}$ The Rwandansupported CNDP had already rejected reintegration, continuing its military activity. Finally, many Yakotumba members felt disillusioned with the DDR process (Demobilised Combatant from Mai Mai General Dunia 2010; Informal 
Conversation with Yakotumba members 2010). Politically, the Mai Mai movement created out of the 1998-2003 war was marginalised from the power distribution of the 1+4 formula. It reproached the Government for not acknowledging that successful resistance against the rebellion and foreign occupation in the East had been due in large part to its actions. Additionally, the electoral results were contested. These military and political concerns went hand in hand with the Mai Mai criticism about the lack of social and economic development. As such, according to a Mai Mai Yakotumba member, they understood that 'the DRC kept being open to foreign intervention' and, although this had turned from a military to a political strategy, they had 'judged it necessary to create the maquis and oppose the Government' (Mai Mai Yakotumba Combatant 1. 2010).

Interpreting the Fizi conflict within patterns of state-making and resistance is not straightforward. The dynamics of conflict in Fizi have been read as those of ethnic conflict, challenging discourses about social justice as being manipulated by local elites. The so-called autochthonous/allochthonous conflict became even more salient in the context of Mobutu's Zairianisation and Bisengimana's policies concerning land, political representation and nationality. ${ }^{12}$ Currently in Fizi there is an important ethnic element in the connection between, on the one hand, Yakotumba's perceptions of Kabila as a Rwandese or as a facilitator of Rwandan economic expansionist agendas in Eastern DRC; and, on the other, the fact that the Banyamulengue community are largely of Tutsi origin, having offered support or been supported at crucial times by the CNDP, M-23 and Rwandan officials (FARDC General (no. 146) 2014; UN Group of Experts 2008a: paras 65-6). This is added to the fact that FARDC deployment in the area was ex-CNDP after the 23 March agreement (FARDC Colonel (no. 129) 2010). ${ }^{13}$ This discursive connection illustrates a rejection of state and foreign agendas and the hailing of traditional modes of political authority and representation. Even if we were to equate ethnic claims with political ones, or to problematise the boundaries between the categories of ethnic identity and the political, ${ }^{14}$ we would still see that discourses of communal identity are simultaneously discourses of resistance and liberation (Hoffmann 2007: 24). This does not mean necessarily an ethical modus operandi. This is the challenge that violence brings. Mai Mai Yakotumba have been accused of killing, stealing cattle and hassling Banyamulengue herders (ADEPAE et al. 2011: 62; Banyamulengue Sheep Herder 2010). Violent actions need to be seen as conditioned (not justified) by a broader context of war, where there is a vicious circle of armed conflict, arms trafficking, military operations and several statebuilding projects that fuel the motivations for further violence.

\section{Bunyakiri: Simba-Mai Mai and Raïa Mutomboki}

A similar dynamic is found in Bunyakiri. It was the headquarters of the 'biggest' Mai Mai group in the two inter-state wars under General Padiri (Vlassenroot 
2002: 138). ${ }^{15}$ Although in the first instance his troops fought the AFDL uprising because it was largely seen as a foreign invasion, this developed into a fragile agreement to later make Padiri Secretary General of the resistance movement, which was attached to the FARDC (Forces Armées Congolaises at the time). ${ }^{16}$ Hoffmann points out that Padiri had significant influence, since the Mai Mai had become the de facto government in many rural areas that were under its control (2007: 78). As such, the exclusion of Mai Mai representation from the $1+4$ formula had a special impact amongst Padiri's supporters. Many interpreted this as the exclusion of the rural population and as foreign intervention in Congolese affairs. Although Padiri was able to reintegrate, his supporters and those who fought with him see current government politics as a continuation of exploitation with no real development of the economy or peace, and this has been a fundamental factor in the formation of new militias in Bunyakiri. ${ }^{17}$ Similarly, there are those who have reintegrated into the army but whose sons continue as members of the Mai Mai militias in their villages (e.g. Colonel Samy operating in the areas of Numbi, Nyawarowa, Katasoko, Busurunki) (APC Representative (no. 114) 2010).

An ex-Mai Mai Padiri combatant expressed the view that, being disappointed by the Government after the transition, his group saw it necessary to renew the group Simba Mai Mai/MRS in 2006 (Simba Mai Mai/MRS Combatant 2010). Not all members broke with the Government immediately, and indeed this officer,served as a STAREC demobilisation officer for 18 months in 2008 and 2009 (May May Simba/MRS - Axe Bunyakiri [Authors anonymised] 2009: 4-5). However, he regretted that at, the time of the interview in August 2010, he had been paid for only three months. Likewise, when his demobilisation team (formed of other ex-Mai Mai combatants) had to go on a demobilisation mission, STAREC gave them a vehicle without petrol and they received no stipends or food for their journey (Simba Mai Mai/MRS Combatant 2010). This combatant has since stopped believing in the programme, questioning whether the Government was really committed to demobilisation, and has become a spearhead for the creation of Raïa Mutomboki in Bunyakiri. ${ }^{18}$

Since the mid-2000s, Raïa Mutomboki has operated on and off in the territory of Shabunda, South Kivu, largely in response to the insecurity created by the presence of the FDLR in the area and the Government's neglect of this region, which is difficult to reach by road. The FDLR had been operating in the area since approximately 1998 and officially deployed under FARDC after it was reintegrated as part of the steps towards the Sun City Agreement in 2002. Feeling betrayed by the Government shortly after, it retaliated with violence against residents in the area (Stearns et al. 2013: 12-14). Raïa Mutomboki raised as a self-defence militia of (literal translation of the name) 'angry citizens'. As a 'franchise' - that is, not as a group that moves from one place to another, but more as an idea that other groups enacted - this group sprang up 
in other parts of South Kivu such as Bunyakiri (Stearns et al. 2013). In Bunyakiri, old Mai Mai members helped to organise the movement and taught it tactics and how to operate weapons (Raïa Mutomboki combatant (no. 182) 2014; Simba Mai Mai/MRS Combatant 2010). For one Raïa Mutomboki combatant this was not only a strategy of self-defence, "it was a defence of our territory and our lives, after we have understood that we were being demobilised to allow others to occupy our lands' (Raïa Mutomboki combatant (no. 182) 2014). Raïa Mutomboki has been largely successful in clearing the area of FDLR, representing a radical rejection and challenge of the state's monopoly of violence and of the peacebuilding strategies in place.

These examples from Fizi and Bunyakiri illustrate that a discursive critique and a denial of state legitimacy can take the form of armed struggle too. These groups represent trends across Mai Mai groups in the Kivus (Demobilised Combatant from Mai Mai General Dunia 2010; Demobilised Mai Mai Padiri Combatant 2 2010). Peacebuilding and the reconstruction of state authority are read largely as an elite affair which maintains the exploitation of rural areas while placing them under military rule. As a form of rejection and mitigation against this, militias become a tool of opposition and a source of security and provision of protection.

\section{Protection and security}

The militarised context pushes the population into a defensive stand. Militias are what Scott calls a 'state effect' - a 'symbiosis' of state expansion, state violence and its rejection (2009: 26). Popular militias are a response to militarised rule, land seizures and insecurity. Security is a constant concern not only for Mai Mai militias but also for the population where the militias belong. ${ }^{19}$ Although, as explored below, popular support for Mai Mai militias is not generalised across time and space, and although many times militias have become a menace to residents, whenever this support is granted it responds largely to a concern for protection. Seeking protection through Mai Mai militias is a denial of state authority and of legitimacy to the peacebuilding discourse of protection. It is done as the least-bad option and could be seen as a self-regarding claim (Morvan 2005: 95-8). The denial/mitigation of the violence generated by state-making is not the intention so much as for individual or collective survival. Yet it is undermining of the authority of the state and the peacebuilding actors.

A professor from the Catholic University of Bukavu argued that the war has made popular classes use the Mai Mai militias not only to defend themselves against foreign armed groups but also against the state (Université Catholique de Bukavu Professor 2009). For this professor, this is in the context of the clash between customary and state land policies. The dual customary and administrative land-property system privileges rich owners who can have access to a land 
title (Vlassenroot 2006). In these cases popular militias confront the state because 'it behaves as a foreign power and not a power that is at the service of the population' (Université Catholique de Bukavu Professor 2009). The implication is that, in the context of war, Mai Mai militias are also used to protect the population from land expropriation.

\section{Fizi}

For Fizi residents, the major threat they face is the FARDC, even if Mai Mai Yakotumba has also committed abuses against them. ${ }^{20}$ Interviewees in Baraka criticised Yakotumba, but they felt closer to them than to state administrators or the FARDC. ${ }^{21}$ This was exemplified by the way a member from a NGO articulated her complaint about the negative effects of the war on women. She stated:

We continue with all those armed groups ... here, there are the regular army, the Government and the militias that are in the forest, they continue to make violence. The women, they go from Baraka to Kafolo for example to get provisions, and they [the mentioned armed groups] continue the violence. They all put a problem for us, the FDLR, the FRF, the Mai Mai and the army ... The Amani Leo came here to get the FDLR that are located $250 \mathrm{~km}$ away. But instead of going there, they have stayed here. They have started in Makobola towards Fizi centre, there were no FDLR there! Yesterday the FDLR attacked the post of FARDC in Nyange, in the border between Fizi and Kalembe ... now, the Amani Leo have come to do what?... They should go. (FEDI Representative 2010)

Another NGO worker stated that the solution to the ongoing insecurity in the area was for all militias to demobilise or reintegrate into the army. However, he recognised that for the ordinary people it was the army and not the militias that created the main problem. He stated: "if you ask the population, what do you want to be done here? They are going to say: that the Amani Leo go. The militarisation of the area is a problem' (Human Rights NGO Representative (no. 127) 2010). He then continued to argue that the reason for the militarisation was the resistance found in the area:

There is a lot of resistance, there are a lot of weapons that do not come from the Government and that do not submit to the orders of the Government. Yes the presence of Amani Leo is a problem for the population, even more than the Mai Mai, but I think the problem of the continuation of the Mai Mai is an ideological and ethnic problem. (Human Rights NGO Representative (no. 127) 2010)

These words summarise many of the arguments that have so far been put forward in this chapter. The reliance on popular militias to provide security, added to a sentiment that sees the state either as directly responsible for the situation or as not doing anything about it, illustrates the patterns in which resistance takes place. Even if this is seen, as the interviewee sees it, from the perspective of ideology and ethnic confrontation, the reflection illustrates the popular 
perception that the FARDC is a menace, whereas the Mai Mai militias are the least-bad option. Those who are not engaged directly in the militias regret the militarisation of daily life. However, they generally feel more threatened by the FARDC and protected by the Mai Mai, with whom they have a more equal relationship. After all, Mai Mai combatants could be members of their families, including husbands and sons.

\section{Bunyakiri}

In Bunyakiri, residents have been threatened by both the FDLR and the FARDC. In August 2010 (during fieldwork) the FARDC brigade stationed there had been able to reduce the abuses committed against the population by the previous brigade. However, population were still threatened by the special operations at the time, the Amani Leo. The cycle of FDLR activity linked to the Amani Leo presence had a direct impact on displacement from areas of cultivation and hence on impoverishment. Bunyakiri had turned into a sort of "island of refugees' because the FDLR had the area almost completely surrounded. There were often incursions into the town and many residents had been displaced or could not access cultivated lands (Action Pour la Paix et la Concorde 2009).

Speaking in Maibano, the Secretary General from the Chefferie of Buloho pointed out several local conflicts related to land and to customary leadership. However, for him, the existence of local armed groups was a direct consequence of the persistence of the FDLR in the region (Buloho Chiefdom Secretary General 2010). ${ }^{22}$ A local human rights organisation stated that the local Mai Mai groups had their own interests, but they were combating the FDLR and they were not there to abuse the civilian population (Voix de sans Voix Representative 2010). Similarly, a representative from an NGO of women survivors of rape stated the situation of threat that women faced, generated by all armed groups. However, she regretted that: 'We have to live with the Amani Leo and we never know with which intentions they are coming' (AFIP Representative 2010). The sentiment she conveyed was that whereas they had an opportunity to react against the Mai Mai and the FDLR, even if minimal, in front of the army they felt defenceless. ${ }^{23}$

The solution against the FDLR that was brought by the Government and supported by MONUC/MONUSCO was for Bunyakiri residents, as for many in other Eastern regions of the DRC, more of a curse than a blessing. The Secretary General of the Buloho chiefdom spoke against the FARDC strategies to fight the FDLR: 'Kimya II has been a disaster, they were there to hunt the residents, their fields and their crops, they pillage, they destroy everything ... Then they brought Amani Leo, which has done exactly the same, the population does not have any hope anymore' (Buloho Chiefdom Secretary General 2010). This administrator summarised a widespread sentiment amongst residents in Bunyakiri, Bulambika 
and Maibano. ${ }^{24}$ Most political representatives, whether administrative or customary, expressed their regret regarding an army that was 'a disorder', while pointing out that 'we cannot speak about it' (Notables at Maibano 2010; Voix de sans Voix Representative 2010).

The situation had a direct impact on the perception residents had of MONUC/ MONUSCO. Residents kept wondering what the role of MONUC/MONUSCO was if the FDLR's positions were known and yet not targeted. Not surprisingly, rumours of UN collaboration with the FDLR, as seen in the previous chapter, spread easily amongst residents. In a focus group with the youth of Bunyakiri, most participants stated that they could not understand why the FDLR was $4 \mathrm{~km}$ away from the village without the UN doing anything, a situation that had already been like that for approximately 15 years. 'Today', one of them said, 'we cannot go to Bukavu as we used to without feeling threatened; our parents long ago stopped cultivating their lands because they have been occupied by the Interahamwe' (Focus Group Young People Bunyakiri 2010). As such, they said, 'this situation has made people furious and as a result, some have taken up machetes, others rifles, in order to constitute themselves as militias of popular defence' (Focus Group Young People Bunyakiri 2010; JMAC Officer 3 2012; see also: Zounmenou and Kok 2012). As a matter of fact, by March 2012 Raïa Mutomboki had expelled the FDLR from Bunyakiri. And although their subsequent activity has remained ambiguous, as a source of self-defence, of violent pursuit of particular village interests, and as the meddling of provincial and national actors, most residents still see them as a force of their own, as a source of protection and security. This was captured in several interviews. For instance, for a civil society representative 'all the population has been united around them [Raïa Mutomboki]' (Civil Society Representative 2014). For the Burogoya Civil society delegate, 'Raïa Mutomboki are a force organised by the people and for the people' (Buroyoga civil society delegate 2014). This motivation to protect residents from the FDLR goes hand in hand with the need to cultivate the land and get on with their life. In this situation, the desire for normality, to put it in Hibou's terms (2011a; 2011b), is not to 'accommodate' to the situation of insecurity and army rule, but to act upon it, even if by violent means.

Overall, the search for protection and security is a pattern in all Mai Mai groups. What it shows is that the need for protection is not generated by a lack of state authority, but from the ways in which state authority is asserted. Although some Mai Mai groups illustrate the engagement of the civilian population in forms of state violence, the cases seen above, especially through the provision of protection and security to the civilian population, represent patterns of resistance in a context where state-making and peacebuilding agendas neglect civilian protection. This becomes more clearly visible when explored alongside the aspirations embedded in Mai Mai ideology. 


\section{Aspirations and agenda advancing}

Rejection of, and protection from, government agendas, war and state-making do not stand alone; rather, they are embedded in a broader system of ideology, religious beliefs and political aspirations. These include the reaffirmation of forms of local political authority, political participation and land distribution. Although these refer explicitly to the current context, they resonate with broader historical, religious and cultural understandings in Congolese rural areas. The Mai Mai militias and their leaders, as previously noted, contextualise themselves in the specific traditions of resistance against domination that have taken place in the DRC since colonisation. Thus, these agendas are better seen as aspirations, which simultaneously overlap with and reinforce elements of rejection and protection.

Mai Mai militias articulate their agendas around a 'nationalist ideology', aiming for the development of the DRC. It is based on a common reference across the DRC where a 'patriotic mentality' means acting for the well-being of all Congolese. Although vague, it reflects the construction of ideas of social justice that were explored in the last chapter. The articulation of specific political agendas comes with a religious armour that links cultural understandings of justice with historical traditions of oppression and liberation. ${ }^{25} \mathrm{In}$ an analysis of the Mai Mai groups of the Uvira-Fizi region, the underlying prophetic and religious element of these groups is noted:

Fizi also has numerous mistico-religious movements, where the leaders present themselves as local 'gods', porters of messages about the liberation and emancipation of the population. At the heart of that society, security-wise in crisis, that messianism of war and self-liberation is alive within the 'armed groups' where the core of their prayers devote themselves to prophecies of victory. Those links with the 'armed groups' make of those religious movements spaces of popular mobilisation.

(ADEPAE et al. 2011: 85)

This study illustrates that popular aspirations for liberation are expressed through religious and mystical discourses, sifting through Mai Mai ideology and practice. Important to Mai Mai ideology is the discourse of 'hatred' against the 'foreigners'. As noted in previous studies of Mai Mai militias, this needs to be understood not as ethnically based but, rather, as a construction of the 'unpatriotic element' as a symbol of oppression (Lubala Mugisho 2000: 214-16; Vlassenroot 2002: 130-3). The resurgence of militia activity in the Kivus and elsewhere maintains these ideas. ${ }^{26}$ For instance, a representative of Mai Mai Yakotumba notes:

We were convinced by our brothers in the Government that it was a nationalist government, but in reality, we have realised after the transition that it is a government that just wants to capitulate the Congo, they are the thieves that want to leave the country in the mess it is now, only to keep pillaging ... it has come in by the 
window, it is not even a legitimate government. (Mai Mai Yakotumba Combatant 1. 2010)

Against this, the Mai Mai's discourse of emancipation is simultaneously created by critiquing the Government for pursuing foreign agendas while locating themselves in a historical tradition of resistance: 'We want sustainable peace, not a peace that goes in three seconds ... not a peace in servitude, a peace of subjection ... that, we will never allow ... our kids here are resisters by birth. ${ }^{27}$ The Government represents for Yakotumba members this 'fragile peace' understood as an order of submission. They are hence convinced that 'sustainable peace' is only achievable through 'conquest and not through dialogue'. The exercise of conquest is not only aimed at Baraka or Fizi, but is national in scope. 'We want a responsible government for the Congo that respects human rights, brings a prosperous society, where we do not speak of war any more, where there is no discrimination, with the aid of god.' As this interviewee continued to elaborate, the 'national' ideal is formulated not as a project of expelling the foreigners, but as eradicating oppression and implementing development and political participation.

In a similar way, the actions of ex-Mai Mai Simba/MRS and the formation of Raïa Mutomboki were justified as a critique against the Government for being 'foreign' and as a need to realise the population's aspirations:

Kabila is not Congolese, they say he is from Hewabora, but we know he is not ... he does everything opposite of what people want ... the teachers are not paid, the army is not paid, the public servants are not paid ... there is social injustice ... our politicians are liars, thieves, corrupt politicians that go against the constitution. ${ }^{28}$

The constitution encapsulated popular aspirations to a certain extent, which explains the popular support it received: 'People voted "yes" to the constitution, their aspirations are seen there, they want justice, schools, good public services ...' These aspirations are well captured by what this combatant called 'the movement': 'We aim to establish a government that is based on the ideals of socialism, which promotes civic and moral education and endogenous political and economic development for the restoration of Congolese dignity.' So, although Mai Mai militias have a local attachment and an ethnic component, their ideals go beyond these identities. Yet, despite this, the way in which they speak of liberation and a national agenda has been interpreted as a façade to justify criminal activity.

\section{Social justice as a façade?}

Some scholars, policy-makers and NGO researchers have argued that these motivations are just a façade. For example, Alden, Thakur and Arnold argue that the continuation of militias in the DRC follows an impulse for personal enrichment where Mai Mai's discourses of social justice are a masquerade without 
substance (Alden et al. 2011: 15). Others argue that the real drivers for these militias are historical conflicts over land and customary leadership (Autesserre 2006; 2012a). Some Mai Mai themselves have criticised the mushrooming of militias as an opportunistic, self-serving activity devoid of political significance. ${ }^{29}$ They criticise this as 'hillism', ${ }^{30}$ articulated as a mockery of those who defend their own 'hill' and do not have a broader political programme for the 'nation'. It is also in this vein that the 'true' and 'false' Mai Mai, the 'warrior' against the 'adventurer'31 comes in. The difference is articulated between those who 'truly' protect the population under a patriotic agenda and those who do not.

These aspirations illuminate the patterns in which resistance unfolds. Although existing land and ethnic-based conflicts could have caused tensions and even violence at earlier times, this was far from the devastating war that has been taking place since 1996. Additionally, as advanced in the first two chapters, one of the distinct characteristics of the DRC conflict is the challenge to the notion of the local as a distinctive sphere from national and international. Rather, it is their co-constitution that unearths how different agendas are intertwined in a fluid, changing context. At times they are the most reliable security provider, even against the FARDC, yet at other times they are predatory and impose authoritarian rule. They also represent the militarised masculine version of a struggle for social justice. Amidst this, it is not possible to ignore that many combatants blame state agendas for the militarised context and the subsequent political, social and economic underdevelopment. Despite these fluid boundaries, the motivations underpinning Mai Mai militias and their support illustrate that resistance is defined by a context of domination. Even so, examining more carefully to what extent popular militias have a popular membership is imperative to analysing them as tools of everyday resistance in a peacebuilding context.

\section{The popular element in the Mai Mai militias}

This book has been arguing that everyday resistance is better conceived as an activity of subordinate groups. Not only is this a closer application of the everyday framework, but it also allows for narrowing the scope of the concept. Additionally, the practices of statebuilding generate violence and extraction, reproducing conditions of domination, war and poverty. Nevertheless, if Mai Mai militias have been used as proxies by different governments, elite factions and MNCs for their own agendas, it is imperative to elucidate the extent to which Mai Mai militias are tools for popular classes' resistance and the extent to which this popular element is represented in their membership.

Additionally, when popular support is granted, it is neither unconditional nor generalised in any one village. It is more accurate to speak of a tendency to rely on these militias to confront the army, other armed groups and advance security, land and political participation agendas. The fact that some of these 
militias represent another source of violence and domination against the population makes this popular support contingent. Violence remains a minority response in comparison with discourses and survival. Yet it is another tool in a broader catalogue by which subordinate classes confront everyday forms of domination. This section gives a brief account of popular support through membership and goods provisioning. It then provides a more extensive discussion through the analysis of government and UN strategies to break the solidarity between civilians and militias.

\section{Membership}

In 2002 the UN estimated the number of Mai Mai combatants active in the two Kivus to be between 20,000 and 30,000 (UN Secretary General Kofi Annan 2002: 13). In 2009, a report by Human Rights Watch calculated that there remained around 22 Mai Mai groups with up to 12,000 combatants (Human Rights Watch 2009: 4). However, as stated in an unpublished report, a UN DDR action in 2010 was expecting to demobilise 28,375 Mai Mai troops only from South Kivu (MONUC DDR Unpublished Report cited in ADEPAE et al. 2011: 69). ${ }^{32}$ Although voluntary membership is contested due to practices of abduction, their members are largely young men, coming from the rural, unemployed, and unschooled sectors of the population, living with few economic resources. ${ }^{33}$

Additionally, although many Mai Mai militias' leaders and original instigators are the more educated, military and notables of particular villages, these are hardly representative of the elite. ${ }^{34}$ There are exceptions, and there are also those groups who, like Mai Mai Yakotumba, have operated for a long time and through different dynamics, engaging with state representatives at different levels (Stearns 2013b). ${ }^{35}$ But generally, like Yakotumba himself or Jean Musumbu, a local healer and spiritual leader who led the formation of the first Raïa Mutomboki, these leaders do not represent state-based authority or large landowners (Vogel 2014a: 310). Rather, they should be seen as what Scott calls 'translators' or 'vehicles', whose more educated position enables them to play as representatives (2009: 296 and 309). In a study focused on the militias of the Maniema province, Amuri Misako argues that the resurgence of Mai Mai responds to a reinforcement of influential ethnic groups and their elites rather than their replacement or insertion of subordinated ones' (2008: 13). However, for Misako this did not affect the fact that Mai Mai militias were a 'mode of political participation of rural masses' (2008: 3). Misako also points out that the upsurge of popular militias corresponds to a reorganisation of the rural political space (2008: 13). As seen in the works of Wolf and also of Scott, peasants' political struggles and political aspirations need to be analysed in light of their reliance on their own authorities and their reticence towards outsiders, whether 
they are foreigners or nationals (cf. Wolf 1971; Scott 1985). The overwhelming perception gathered in interviews from representatives of subordinate groups, civil society, the Government, the army and UN officials is that there is substantial overlap between the civilian population and Mai Mai militias. ${ }^{36}$ This idea, it must be stressed, is expressed throughout the militias' non-elite membership. However, it is also a fact that the non-military active population provide key support for the continuation of these militias.

\section{Provisioning: weapons, food, protection and information}

Another area where popular support is visible is in the provision of different goods and services for the militias to operate and survive. Although militias may receive incentives from deputies in Kinshasa, the bulk of their support in terms of weapons, ammunition, protection and information comes from the popular classes. ${ }^{37}$ Many of these militias have also settled around mining areas and are now part of networks of resource plundering and parallel exploitation. ${ }^{38}$ However, this is further evidence of the overlap between the civilian population and popular militias. At times resources are exchanged or services are paid, fostering relations of mutual support and reciprocity. These networks of support and exchange represent a great challenge not only to the authority of peacebuilding but also to the DDR(RR) programmes that are at the heart of it (UN Security Council 2000 and subsequent mandates). ${ }^{39}$

\section{Weapons}

Significant funding has been put towards a programme of disarmament by which for every weapon the Government pays US\$100 in Kinshasa and US\$50 everywhere else. ${ }^{40}$ However, these incentives have been subverted by the availability of weapons. Many interviewees and informal interlocutors declared how easy it was to buy a Kalashnikov for US\$30. ${ }^{41}$ The same is true of the programmes of demobilisation, which find it very difficult to persuade combatants to leave the armed groups, even with substantial economic benefits (Comité de Paix Representative 2010; Demobilised Combatant from Mai Mai General Dunia 2010; Marriage 2007). The problem that resistance to disarmament poses to DDR programmes is that authorities believe their weapons can be handed over to Mai Mai combatants (Assistant Administrator to Baraka's Civil Authority Representative 2010; Human Rights NGO Representative (no. 127) 2010; DDRRR Officer, Uvira 2010). Mai Mai Yakotumba members narrated how they make use of solidarity kin and religious-based networks to access the weapons held by villagers (Informal Conversation with Yakotumba members 2010). Other Mai Mai combatants also recognised their use of family and kin networks to take advantage of trafficking in conventional weapons and to gather bamboo and gunpowder to fabricate their own guns (Demobilised Combatant from Mai 
Mai General Dunia 2010; Demobilised Mai Mai Padiri Combatant 2 2010; Mai Mai Yakotumba Combatant 1 2010).

The Mai Mai do not only rely on these networks to gain access to weapons. They also steal them from the army and even from the UN blue helmets. As a Raïa Mutomboki combatant explains:

we have combat them [blue helmets] in Kamananga with machetes and hunting weapons calibre 12 and then we have found that in their hideouts they had ammunitions and weapons from FARDC, which we have taken. Then we have carried out another attack against the FARDC, we combat with the weapons of our enemies. (Raïa Mutomboki combatant (no. 187) 2014)

They claim to use magic formulas that protect them from dying, which enable them to attack the army to collect their arms. A traditional formula, giving the Mai Mai their name (Mai or Mayi means water in Swahili and Lingala), is based on the combatants bathing in water blessed by prophet Kimbangu. This bathing protects them from the bullets, which at the moment of impact are turned into water. Another formula is the fabrication of a potion called 'dawa', 'Formula 115 ' or 'grigri'. ${ }^{42}$ Once this potion is swallowed, it provides protection from death. Being under the effects of these formulas, Mai Mai combatants would attack a battalion, killing its members or making them flee, and then collect their weapons (Demobilised Mai Mai Padiri Combatant 2 2010; Mai Mai Yakotumba Combatant 1 2010; Simba Mai Mai/MRS Combatant 2010).

Another source of weapons and ammunition is illicit trafficking, mainly of minerals. Mai Mai Yakotumba is a case in point. Being in control of part of the coast in Lake Tanganika gives it access to Tanzania and Burundi. It has been known to capture boats (CCAP Representative 2010; Mfaume 2010). It also controls mines whose profit is used to purchase armaments (JMAC Officer 1 2010; UN Group of Experts 2011: 4-5). However, the transport and hiding of many of these arms is carried out through networks amongst the civilian population and not necessarily amongst combatants.

\section{Food, protection and information}

Although weaponry is fundamental for the continuation of militias and their military successes, they rely on other services such as food, protection and intelligence for survival and strategic planning. Militias tend to be hidden in the forest, although some of their members live in the villages. Most of the time they do not have the resources to set up self-sustaining camps. So, for instance, an NGO representative who was active in training women in self-defence in the territory of Kabare (South Kivu) states that 'their enemy were the FDLR and the FRF ... the Mai Mai [General Padiri] just came here to eat and get provisions' (Demobilised Mai Mai Padiri Combatant 1 2009). Although this would be typical of a family connection, the support network seems to be much greater. 
The Raïa Mutomboki counts on popular support in Bunyakiri, but many interviewees reflected that this support is requested when people cannot really grant it and ends up being obligatory or exploitative. For example, the spokesperson for Femmes Unies stated the following:

We don't have any problems because they don't rape us, but they make us cook for them and ask our husbands to go with them, even sing for them songs of honour. We have now a group organised that keeps food and supplies for them, in case they come. We owe them respect, most of the time they are husbands or fathers of our children, what they demand is what keeps us as a family. (Femmes Unies Representative 2014)

Buroyoga civil society delegate confirms this:

Our women suffer, especially those who can't leave the town when the Raïa Mutomboki come. They demand them to go with them to help them carry their supplies or to cook for them. The women do that quickly because they love them inside and think that otherwise no one will liberate them from those who pillage, kill and rape everywhere. (Buroyoga civil society delegate 2014)

Civil Society secretary in Kichanga stated the following:

The Raïa Mutomboki come suddenly without us previously knowing, then they ask or oblige people to leave what they are doing to join them. They can ask you to stay with them for several hours or even to stay overnight. They often find us tired, after having worked in the fields, and then, imagine, they tell you to stay with them and they make you transport their supplies, sometimes up to $70 \mathrm{~kg}$ for 8 hours. [...] we do that because we fear of what can happen if we don't. (Civil Society Representative 2014)

This is added to the displacement and human rights abuses that are committed as a result of attacks against the FDLR or the FARDC. Still, it is not possible to make a clear-cut division between these Mai Mai groups and the civilian population.

Speaking about Fizi and Yakotumba, an NGO researcher noted that the strongest support Mai Mai had were from its own clans and families. 'It is from here that they take what they need: provisions, munitions, information ...' (Human Rights NGO Representative (no. 127) 2010). However, support has to be bigger than the clan, by necessity. The interviewee noted that 'they also have their networks from which they can send a messenger even to the heart of the army to gather information'. Different services are sought, ranging from the closer environment of the family to the clan, to the ethnic group, to the broader political, military and economic networks and other Mai Mai militias. As will be noted in the next chapter, these networks and exchanges are also part of strategies of everyday survival against poverty.

A FARDC colonel in charge of Fizi had no doubt about the solidarity and overlap between the Mai Mai and the population. He pointed out firstly that 
Kimya II had failed because of a lack of support from the population, and that 'in fact they [the population] kept passing information to the armed groups' (FARDC Colonel (no. 129) 2010). For this FARDC colonel, it was clear that 'what makes the whole thing complicated is the population', and he added 'what enrages me when I see how a soldier is killed is to think, how many houses has he passed by to arrive there? Why has he been hidden? Why hasn't the population given any information?' (FARDC Colonel (no. 129) 2010).

On the whole, Mai Mai's strongest and most reliable support is the population. Gradients of support are likely to develop from the family to the clan, to the ethnic communities and then onto broader networks. This support, even if it cannot be generalised across the whole of the population, represents a challenge to the statebuilding mission. A main obstacle to inter-community dialogue and local peacebuilding strategies is Mai Mai's conviction that the laying down of arms means subjection to the rule of the army. Evariste Mfume from the NGO Solidarites de Volontaires pour l'Humanité summarised it succinctly: 'If the communities were to get together and say no to the armed groups, the problem would be finished ... but each sees in their armed group their protector' (2011). In Masisi, Bunyakiri, Fizi and Baraka, fieldwork illustrates not hatred against other communities but mainly fear of the army, the FDLR and other armed groups (Banyamulengue Sheep Herder 2010; CCAP Representative 2010; FEDI Representative 2010; Fizi SOCICO Representative 2010; Gakunzi 2010). Peace is highly desired but there is a general distrust that the Government and the military can provide it. Significantly, the breaking of ties between the civilian population and their armed groups lies at the heart of many UN and government statebuilding strategies.

\section{Desolidarising popular classes and Mai Mai militias}

The popular support given to Mai Mai militias becomes a visible fact when we observe the significant resources the Government and the MONUC/MONUSCO invest to 'desolidarise' the population from the Mai Mai militias and 'sensitize' 'civil society' to 'accept state authority', 'lay down the arms' and 'live pacifically with the army'. ${ }^{43}$ UN Civil Affairs, for instance, has these 'sensitization' exercises as part of its mandate for supporting the restoration of state authority (MONUSCO Civil Affairs 2012b). 'Since 2011' MONUSCO Civil Affairs claims to have 'reached about 7000 people in 17 different localities in North Kivu, South Kivu, and Ituri District' in a 'sensitization campaign on the rights and responsibilities of the administrative authorities and local population' (MONUSCO Civil Affairs 2012a: 7). STAREC has done its own 'sensitization forums' throughout those provinces with the support of civil society organisations (e.g. Ahoussi 2009). STAREC sessions are done by civil society representatives because "people do not have any trust in the political class' (Kikongo Kisimila 2010; President 
of Civil Society Masisi Centre 2011; SOCICO - North Kivu Representative 2010). Their aim is to convince people to stop supporting the armed groups, to stop guarding their weapons and to 'pacifically co-habit with the army' (SOCICO North Kivu Representative 2010).

\section{An example from Baraka and Fizi}

One such 'sensitization' activity is the workshop organised by MONUC Civil Affairs in Fizi and Baraka (South Kivu) to ease the sour relationship between civil society (population) and the military (Participant Observation XIV 2010). The purpose of this workshop is best described in the words of the Civil Affairs officer in his opening speech: "there needs to be collaboration and cohesion between society and power in order to render results towards peace and stability' (MONUSCO Civil Affairs Officer (no. 191) 2010). This officer is voicing not only the perception that people's solidarity with the armed groups is a real impediment for the statebuilding mission, but the extent to which resistance is successful in denying and subverting state agendas.

The significance of the Fizi territory has already been noted. Aside from the tense relations that have developed between the Tutsi-Banyamulengue population and the Bembe population, the 23 March agreement, by which CNDP elements integrated into the army and were spread throughout the Eastern provinces were also felt in this region. This military deployment fed the theories claiming that Rwanda would be infiltrating the army in its attempt to annex a part of the Kivus. Many of these reintegrated CNDP elements are of Tutsi origin and include many who speak only Kinyarwanda. ${ }^{44}$ This situation, in addition to the military strategy of scattering an utterly under-resourced and undisciplined army throughout the territory, has created a low-intensity war between the population and the military. As previously noted, this strategy entails those military elements living with and off the civilian population. Although many brigades engage in multiple commercial activities which complement local commercial networks, residents are forced to provide the military with labour, food, housing, sex and information, while the military are a source of violence and predation. ${ }^{45}$

As such, this so-called 'sensitization workshop' illustrated that the military is perceived as an enemy by the civilian population, and that the military and state authorities needed 'civil society' in order to establish state order. The military complained that people would side more with the Mai Mai militias than with them, that people would not give them information, that the population was hostile to them and that they did not respect authority (Participant Observation XIV 2010). NGOs present at the workshop complained about the military's human rights abuses, including rape, arbitrary arrests, extortions, theft and abuse of authority. They also complained about the fact that the military did not speak their language and that the population were treated like criminals, because 
of the perceived support for the local militias. One of the UN officers moderating the sessions at one point explained what role each was supposed to play: "the army, the police and civil society all have a role to play in society under legality'; for example, he said, 'the teachers must teach and not take up arms'; 'the soldiers must protect the population and not steal from them' (Participant Observation XIV 2010).

This workshop demonstrated two interesting factors. One was that the civil society/population component, represented by local NGOs and religious organisations, had links to the Mai Mai militias. Two days after the workshop, members of this 'civil society', in an attempt to show good will, passed information to the commander of the area to notify him of an incoming attack on one of his battalions. Similarly, despite the imbalance of power, it was demonstrated that people retained a substantial amount of control over what takes place on the ground. Army and state administrators had much to gain from the withdrawal of civilian support to militias and they could obtain concrete commitments from the population: pass information, stop making donations, stop giving food and shelter to the militias. However, there were no similar commitments on the part of the military and the state administrators: stop abuses, rape, robbery, abuse of authority and illegal tax collection. Still, the frustration of the military and administrators was that without the help of the population they could not get rid of the armed groups (FARDC Colonel (no. 129) 2010; FARDC Officer (no. 162), Baraka 2011).

The experience of the workshop also revealed 'civil society' as an ambiguous partner for statebuilding strategies. This ambiguity has been established by research conducted within both policy and academic circles (DFID 2010: 56-7; Mac Ginty 2011: 15-17 and Ch. 8). Mac Ginty, for instance, has shown the thin line in Northern Ireland between 'civil society' and 'armed groups' (2011: 194). This is important because, whereas civil society is seen as a pillar for liberal peace in order to legitimise a project of statebuilding based on good governance, civil society's role in this situation is not straightforward. It can act as an antagonist rather than a partner.

\section{'People are intoxicated'}

An examination of the efforts to 'desolidarise' the civilian population from the Mai Mai militias illustrates the non-elite support for these militias and the motivations behind this support. Firstly, it is possible to establish a significant overlap at the non-elite level of the population, even if the boundaries of class, resistance and domination are blurred and complicated in the DRC context. Secondly, these efforts highlight underlying elite assumptions. Precisely because these militias represent the subordinate groups in society it is not uncommon to observe how DRC Government representatives, UN officials and NGO members, far from making an analysis of people's political agendas, think of the Mai Mai as 'the 
poor' or 'marijuana smokers' or just remnant 'embers' (Amani Leo Operations Officer 2010; Catholic University of Bukavu Seminarist 2009; Heal Africa Representative 2009; MONUSCO Political Affairs Officer (no. 63) 2010; Stearns 2012b: para. 1). From these analyses the reasons explaining popular support for Mai Mai militias can be summarised in the statement of an NGO officer: 'people are intoxicated' (Human Rights NGO Representative (no. 127) 2010). People's support of the militias is seen as the action of helpless, ignorant, 'lumpenproletariat'-type of people, manipulated by politicians to fulfil their own interests. These assumptions illustrate elites' hidden transcripts. Delegitimising and mocking the militias by denying them any political significance and linking them to drug use and human rights abuses is a discursive attack of the form seen in the previous chapter.

Conversely, that state authority is not straightforwardly accepted resonates strongly with what Certeau would see as a popular mechanism that subverts discipline (1984: xiv). The denial of state authority, whether symbolised in the rejection of the army in Fizi, of the MONUC/MONUSCO-backed military operations in Bunyakiri, in the self-defence mechanisms against the FDLR in Bunyakiri, added to the continuous provisioning for the militias, illustrates political choices with collective dimensions that cannot be seen as anything but forms of resistance.

\section{Militarised peace, militarised authority and violent resistance}

The militarisation of peace and the dynamics of violence in the DRC are carried out through both official and unofficial channels in relation to how ideals and practices stick, or deviate from the kind of ideal state. Although at an official level strategies may attempt to concentrate the use of legitimate violence on the hands of the state, the practice of statebuilding has achieved what Mbembe calls the 'socialisation' of violence. For Mbembe, this means that community groups form their own armed groups and remain armed or ally themselves with armed groups as an effect of domination and not as an action of resistance (2001: 45 and Ch. 2). Although Mai Mai militias represent this form of socialisation and many times have become a source of domination and violence to their own constituencies, they represent a challenge to statebuilding and the broader order it is part of. Mai Mai militias signal self-reliance for community protection and hence a challenge to the discourse of protection on which peacebuilding is premised. They are a vehicle towards political aspirations. These are articulated through a discourse of survival, security, political participation and land distribution, which are equated to emancipation. Although their ongoing military activity reifies a militarised context that provokes further domination, Mai Mai militias represent an everyday form of resistance. Not only do they generally operate in 
typical self-defence and non-confrontational ways, but there is also significant overlap between the militias and the non-elite sectors of the population. Either directly or in representation of a larger constituency the Mai Mai deny or mitigate the actions and effects of those that cause insecurity, which is experienced as a form of domination. The cases of Bunyakiri with the presence of the FDLR and the Amani Leo troops, and Fizi with the FARDC are exemplars.

Both MONUC/MONUSCO and the Government defeat their idealised vision of the state in the very praxis of peacebuilding and state-making. The idealised vision of the state, deployed in the sensitisation workshops to desolidarise the population from the militias, involves a civil society that demands services, an army that secures people and a government that provides services to the population. That the Government and the army act as predatory armed groups and the fact that MONUC/MONUSCO, knowing this, still supports a strategy of disarming the population while supporting the military strategies of the Government and the army challenges the approaches by which they want to restore public service, order, development and peace. A significant response from the population when flight is not possible or is unwanted is to join or support the Mai Mai militias.

The fact that these 'poor marijuana smokers' present a challenge to the Government lies not just in their capacity to mobilise illegal resources from mines or weapons. Rather, the main challenge is that they convey the sentiments of a significant sector of the population against domination and are a tool to protect people's agendas of security, political authority and land. These broader political agendas and not just the difficult economic circumstances they endure should be seen at the root of the challenges many demobilisation programmes face. In conversation with a demobilisation officer, it was stated that without programmes providing reinsertion in to a life with enough means of living and a motivating job, it was difficult to persuade combatants to return to civilian life (UPN-DDR Officer 2010). However, as Marriage and Hoffmann show, it is not just the lack of motivating elements to return to civilian life, but the ideological commitments to the armed groups that demobilising strategies do not take into account (Hoffmann 2007; Marriage 2007).

Mai Mai militias represent a violent way of claiming popular aspirations. Yet these weapons of the weak need not to be seen as the summation of other strategies, or as a step forward from the others. Rather, they need to be seen alongside others. Armed resistance, whether it is by supporting the Mai Mai or becoming a combatant should also be seen as an effect of war and statebuilding. Denying and mitigating their effects while advancing alternative agendas is an example of everyday resistance. The next chapter will illustrate in a similar manner how the context of poverty pushes people to organise their own forms of survival as well as challenging authority's claim on the distribution of wealth. 


\section{Everyday resistance, peacebuilding and state-making}

\section{Notes}

1 Majority response in 2005 World Bank survey in 'DRC, economic sector, Governance and Service Delivery' (cited in Trefon 2007: 27).

2 Young notes that Mulele's rebels 'eliminated a central government presence for some months in the northeast quadrant of the country and some parts of the Kwilu district in the southwest' (Young 2002: 20; see also Ndaywel è Nziem 2009: 496-9).

3 ADEPAE's monograph also accounts for socio-political factors.

4 A series of NGO reports and monographs also illustrate this (ADEPAE et al. 2011; Morvan 2005).

5 Wood, Erikssen Baaz and Verweijen, Kalyvas and Bravant and Nzweve cited in Verweijen (2015: 173).

6 This includes academic and policy literature, both international as well as Congolese. See section 'Social justice as a façade?' below. The Commité de Coordination des Activités pour la Paix (CCAP) representative coordinating the first dialogue between Banyamulengue and Babembe stated: 'the problem was not the capacity of the communities to live together, but the influence of the war, the flow of weapons into the area as well as the political discourses that some governments and politicians started to play with' (CCAP Representative 2010).

7 For an earlier analysis of these two areas see Vlassenroot (2002).

8 This is the area from where Che Guevara attempted to organise a revolutionary movement with Laurent Kabila. By 2012, as Judith Verweijen points out, "some of the "brigades" forming part of the larger Mai Mai movement built by Yakutumba in 2007/2008, operated de facto as entirely autonomous groups, and later left the movement. It concerns the 5th brigade under Assani Ngungu Ntamushobora, the 6th under Aoci Behekelwa and the 7th under Mulumba' (Verweijen 2012).

9 Babembe literally means Bembe people.

10 Especially the period immediately preceding the Goma Accords, as described in Chapter 3.

11 Banyamulengue literally means people from Mulengue, in Swahili. Traditionally, this term has been given in South Kivu to people associated with the wave of migrations from Rwanda and Burundi in the early twentieth century, who settled in the high plateaux of the Minembwe massif in between the territories of Kalehe, Mwenga and Fizi, and who tend to be of a Tutsi background.

12 As seen in Chapter 3 this included the transferring of Belgian and white-owned land to selected Rwandan/Tutsi who were made Congolese nationals after the changes in the nationality law.

13 See below the discussion on civil-military relations in Baraka.

14 Thanks to Judith Verweijen for pointing this out.

15 His real name is Joseph David Karendo Bulenda.

16 According to Kasper Hoffmann: 'In 1999 the Mai-Mai were officially recognised as a part of the Congolese army by decree of the then president Laurent-Désiré Kabila, but their operations on the ground were not coordinated by Kinshasa' (2007: 77).

17 This feeling was transmitted by all Mai Mai combatants interviewed in formal and informal conversations. According to APC representative and ex-Mai Mai Padiri combatant, in the case of Bunyakiri this has been felt particularly amongst Mai Mai leaders like General Ziralo, General Kirikicho, Major Janvier and Colonel Sadam (APC Representative (no. 114) 2010; Demobilised Mai Mai Padiri Combatant 1 2009).

18 The issues raised by this combatant were shared by the 11 other Mai Mai combatants interviewed formally and in informal conversations. In conversation with a DDR and 
STAREC officer, although they did not directly acknowledge lack of payment, challenges for funding were raised as a challenge for demobilisation (STAREC Representative 22014 ; STAREC - Amani Leo Representative 2010; UPN-DDR Officer 2010).

19 Scott too notes that rural rebellions have many times been underpinned by a concern for security (1998: 37).

20 Illegal taxation, cattle theft, especially from Banyamulengue farmers, and recruitment of children, although denied by Mai Mai Yakotumba members (UN Group of Experts 2011: 184-7; 657 and 663).

21 During fieldwork in 2010, 12 NGO representatives were interviewed in Baraka. This interpretation was reflected in four interviews with MONUSCO staff and one with UNHRC staff working in Baraka, as well as by two officers working from Uvira and Bukavu, but with direct responsibility of the Baraka-Fizi region. Multiple informal conversations with residents, local NGOs, INGOs and MONUSCO operating in Baraka also supported this view. See also: Alden, Thakur, and Arnold (2011: 116-17).

22 This has been shared by most interviewees in the area (APC Representative (no. 184) 2014; Primary School Teacher 2014; Raïa Mutomboki Combatant (no. 183) 2014).

23 A local human rights NGO representative said that normally complaints about the army could go to the customary security council. However, as the military could participate, the extent to which residents could voice their concerns about the army were limited (APDHUD Representative 2010).

24 The interview took place in the form of a public audience attended by 15 people. These words resonated amongst the group. This was the general sentiment gathered across the fieldwork in the area of Bunyakiri, including Maibano and Bulambika. At the time, it included 14 interviews with residents, 5 of which had a similar public setting. This was also reflected in two focus groups (Focus Group Bunyakiri Women 2010; Focus Group Young People Bunyakiri 2010).

25 Amuri Misako 2008 points out how prophetic religion, the syncretism of Mai Mai militias, is part of its radicalisation (2008: 127).

26 Militia activity is also seen in other provinces like in Ituri, Maniema, Equateur and Bas Congo. Mbembe argues this is across Africa (2010: 196-221).

27 Information in this paragraph comes from Mai Mai Yakotumba Combatant 1 (2010). It was reflected in the rest of interviews with other Yakotumba members (Mai Mai Yakotumba Combatants 2-5 2010).

28 This and the following quotes come from Simba Mai Mai/MRS Combatant (2010).

29 Especially Simba Mai Mai/MRS and ex-Mai Mai Padiri. Others thought these were false accusations coming from the Government, MONUC/ MONUSCO and the INGOs.

30 From the French colline (small hill), they speak of 'collinisme' (Simba Mai Mai/MRS Combatant 2010).

31 Opportunistic, motivated for self-gain or self-aggrandisement.

32 Only 1,749 attended, according to the same report.

33 Abduction and forced recruitment have been reported in Human Rights Watch (2008: 18); UN Secretary General Ban Ki-Moon (2009: 39). For an overview of membership see Lubala Mugisho (2000); Maindo Monga Ngonga (2007); Vlassenroot (2002).

34 An exception is the FRF in Minembwe, which was formed through a split in the military leadership. Still, many disillusioned unemployed youth in the area may have joined since (FARDC General (no. 146) 2010; ADEPAE et al. 2011: 47-8).

35 PARECO's creation was helped by MP Bakungu Mithondeke; as discussed in Chapter 3, PARECO was co-opted by the Government to fight the CNDP (Stearns 2013c: 34). 
36 This was the view gathered from 15 government and local administration officials, 10 military officers, 17 UN officials and two UNHCR representatives. The desolidarisation strategies discussed below also support this view.

37 Several MPs spoke of these dynamics as an obstacle to ending the conflict (Goma MP 2011; Masisi MP 1 2010; Masisi MP 2 2014).

38 E.g. Yakotumba in the Mukera, Ngandja and Milimba mines in Fizi (ADEPAE et al. 2011: 119; see also: UN Group of Experts 2015b).

39 From the DRC Government, there are three presidential decrees (DRC Government 2004a, 2004b, 2004c).

40 The World Bank created a multi-million-dollar donor trust for Disarmament and Reintegration that in 2009 had invested US\$275 million (World Bank 2009: 1).

41 This was available information in all fieldwork locations. It was confirmed by the two demobilisation officers interviewed, all Mai Mai and ex-Mai Mai combatants and was raised in several interviews with MONUSCO and local authorities (JMAC Officer 2 2011; Masisi Territory Administrator 2011).

42 Dawa (medicine in Swahili) is a generic name across territories but the others are also used in Bunyakiri and Uvira, respectively.

43 These words are part of the technical vocabulary of used by MONUC/MONUSCO and STAREC (Ahoussi 2009; MONUSCO Civil Affairs 2012c. esp. Q.1 and 3). 'Sensitization' activities were already attempted by L. Kabila after the 1996 war and at beginning of 1998 war (ADEPAE et al. 2011: 39-40).

44 Kinyarwanda is a Rwandese language. Some of the elements reintegrated in the army do not speak the official languages of the provinces (Swahili and French), let alone the local languages. I was able to observe this during my field trips in Baraka, Fizi and Masisi.

45 Some of these issues were raised in the workshop. They came in several interviews and have been reported extensively as dynamics in civil/military relations (e.g. FEDI Representative 2010; Femmes Père Saint-Simon Representative 2010; Free the Slaves 2011: 13; Human Rights Watch 2009: 3). 